\title{
Organizing Capacities and Union Priorities in the Hotel Sector in Oslo, Dublin, and Toronto
}

\section{Ann Cecilie Bergene}

Senior Researcher, Work Research Institute, Oslo and Akershus University College of Applied Sciences, Norway

\section{David Jordhus-Lier}

Associate Professor, Department of Sociology and Human Geography, University of Oslo, Norway

\section{Anders Underthun'}

Senior Researcher, Work Research Institute, Oslo and Akershus University College of Applied Sciences, Norway

\begin{abstract}
In this article, we draw international comparisons between industrial relations regimes in the hotel sector and compare relevant trade union experiences in the selected metropolitan areas of Oslo, Dublin, and Toronto. We ask how union strategies differ in these different hotel markets, and how strategic choices at a local level relate to industrial relations models, regulatory change, and corporate restructuring in the hotel market. The study is based on interviews with union representatives and key informants in Norway, Ireland, and Canada. The main argument we make is that the reorientation of union priorities and the willingness to engage in innovative strategies that has characterized hotel unionism in Toronto and Dublin is not detectable in the case of Oslo. This might be a result of the relatively strong position Norwegian trade unions have in national industrial relations, but can at the same time leave local hotel unions vulnerable as they are facing low unionization levels and corporate restructuring which they are unable to tackle effectively.
\end{abstract}

\section{KEY WORDS}

Canada / comparative case studies / hotel sector / industrial relations / Ireland / Norway / organizing capacities / union priorities

\section{Organized labor and the challenge of hotel workplaces}

rganizing capacities and union priorities are often associated with systems of industrial relations that vary across space and between national contexts (Thelen 2001). The Nordic model has been characterized by social compromise and a high unionization rate allowing for a strong dialogue between capital and labor, although Mjøset (1987) suggests treating each national model as analytically distinct. The unionization rates in Anglo-American countries such as the United States, the United Kingdom, Canada, and Ireland, on the other hand, have been lower throughout the last three decades and

\footnotetext{
${ }^{1}$ Anders Underthun, Work Research Institute, Oslo and Akershus University College of Applied Sciences, Box 6954 St. Olavs Plass, 0130 Oslo, Norway. E-mail: anders.underthun@hioa.no
} 
marked by a more confrontational style of industrial relations (Aguiar and Herod 2006; Moody 1997; Panitz and Swartz 2003). However, the hospitality sector can be considered as an anomaly in the Norwegian context with a relatively weak union presence. While this is also the case in many Anglo-American hospitality markets, successful organizing drives in large hotel workplaces have taken place in cities such as Las Vegas, New York, London, and Toronto (Gray 2004; Tufts 2006a, 2007; Wills 2008). Hotels have by their very nature a potential for workplace organization due to their less geographically mobile nature and size. That is not to say that building union locals is easy in social spaces characterized by the high labor mobility, labor exploitation, and ethnic and cultural heterogeneity typical of the hotel sector (McNeill 2008; Zampoukos and Ioannides 2011). Competitive pressures and corporate restructuring present challenges for trade unions in their attempts to organize hotel workers. While important contributions have been made in terms of highlighting union challenges and union strategies in particular hospitality markets, comparative attempts have been rare.

In this article we draw international comparisons between industrial relations regimes in the hotel sector and compare relevant trade union experiences in the selected metropolitan areas of Oslo, Dublin, and Toronto. We ask how union strategies differ in these different locations, and how strategic choices at a local level relate to industrial relations models, regulatory change, and corporate restructuring in the hotel markets.

The study is based on qualitative data generated through interviews and secondary data, including fieldwork in Norway, Ireland, and Canada in 2011. We conducted interviews with 15 union representatives in Oslo. Interviewees were chosen from across the union hierarchy, and supported by interviews with employers and contractors. In total, 14 semistructured qualitative interviews were conducted in Dublin with 16 informants. In addition, we participated in a "flash mob" action with a number of activists. Seven of the informants were national officers at SIPTU, one was a regional officer, three were or had been shop stewards at three different hotels, one was from the Irish Congress of Trade Unions, one was from an NGO called the Migrant Rights Centre Ireland, two were TDs (TeachtaDála, members of the parliament) from the Labour Party, and finally one was a researcher. In Toronto, we conducted 17 interviews in total. This included 11 Local 75 staff (management, legal advisors, organizers, and researchers), 4 volunteers and interviews in the Toronto Labour Council and the Ontario Public Sector Employee Union (OPSEU). We also participated in selected staff meetings in Toronto.

The collected data were analyzed collectively by the author by exploring "surprised expectations", that is, how the three cases diverge from the characteristics of their respective national models. We also asked whether there were significant similarities and differences between our selected metropolitan areas. Three assumptions shaped our analytical strategy. First, the selected Anglo-American cities are embedded in national contexts where neoliberal policies have had a deeper impact, suggesting that the coercion on unions would be considerably tougher than in Oslo. Second, Toronto and Dublin are social spaces where multiculturalism and labor migration have a longer history than in Oslo. This is likely to create a less distinct division between the local population and migrant groups perceived as "foreigners." Third, trade unions in Toronto, Dublin, and other Anglo-American cities have gone through organizational innovation in order to represent workers in diverse labor markets. As the three cases represent different trade union cultures, unionization levels, and regulatory contexts, one could expect more 
compromise-oriented strategies in Oslo and more confrontational strategies in Toronto and Dublin.

The article is organized in the following way. We first provide a contextual background for the Oslo, Dublin, and Toronto hotel markets. In the main empirical section, we compare union strategies in relation to issues of workplace organizing, inclusion and representation, ethical consumption, and alliance-building in civil society.

\section{The Norwegian model of industrial relations and its exceptions}

The Norwegian model of industrial relations is a product of social conflict and compromise throughout the twentieth century (Mjøset 1987; Moene 2007). The development of a centralized labor movement, spearheaded by the national federation Landsorganisasjonen (LO) and the Norwegian Labour Party, enabled organized labor to formulate strong demands on behalf of their members, both to the state and to their employers. A high unionization rate in relatively large and coherent workplaces (industrial and public sector) has traditionally been based on a homogeneous social base (white male industrial workers and female public sector workers) which created a shared sense of identity. The orientation toward compromise and social partnership with employers and the state in Nordic industrial relations stands in contrast to more confrontational labor experiences in France, Italy, and the United Kingdom (Hudson 2001; Thelen 2001; Wrench 2004). Moreover, access to income from the offshore oil industry has prevented Norwegian labor from making substantial concessions during the recent financial turmoil.

But as noted above, significant segments of the Norwegian labor market are on the periphery of this ideal-type. Service sectors such as the hospitality industry seem to have developed along quite different trajectories, reminiscent of the neoliberal labor markets in the Anglo-American world; high numbers of labor immigrants, increased subcontracting and outsourcing, growth in temporary staffing, and the deregulation of employment contracts and organizational rights are all central features of neoliberal economies in the Western world (Herod and Aguiar 2006). These are also key challenges to labor in Norwegian hotels. Hotels suffer from a low unionization rate, and as a result the social partnership between employers and employees has been relatively weak and asymmetrical. There were few strikes in the sector before a radicalization of the hotel union in the 1990s, even though the wage gap to industrial workers has been steadily widening (Berntsen 2010). Moreover, violations of the Working Environment Act have only been detected through sporadic inspections by the Labour Inspection Authority or through union investigations.

The persistent use of casual labor in the sector has a long history, but deregulation has opened for new forms of restructuring. A recent rise in outsourcing and temporary staffing present an arduous task to unions and others trying to enforce decent working conditions and organize workers. Changes in restrictions on labor hire post-2000 has led to explosive growth in the temporary staffing industry (even though the "hiring in" of labor is still only allowed when there is a temporary need). In a survey of hotel workers in the Oslo region, however, we found that hotels on the whole did not rely heavily on temporary worker agency staff (Jordhus-Lier et al. 2011). One reason for this could be the already high level of in-house "extras." Still, hotel managers indicated that in 
certain sector such as waiting, an extensive use of temporary staffing workers took place during peak periods. Amendments to the Working Environment Act mean that outsourcing is no longer reserved for noncore business activities. This, coupled with the fact that VAT regulations were changed and a major multinational firm started targeting the hotel market, encouraged hotels to outsource housekeeping departments from 2006 onward. In the Oslo region, approximately a third of hotel workplaces outsourced room cleaning or other functions in 2010 (Jordhus-Lier et al. 2010).

The Oslo region has been organized by the same hotel union for decades, previously known as Oslo og Akershus hotell- og restaurantarbeiderforening, but now part of Fellesforbundet (Local 246). The union local experienced membership growth during the 2000s, in contrast to the national hotel union, and claimed a membership of 2750 in 2012. In addition, the waiters' union, Fellesforbundet Local 249, had 600 active members in Oslo. If we compare the workforce as a whole to the organized workforce, it is clear that waiters are disproportionately well represented, while the opposite is the case for room cleaning staff (Jordhus-Lier et al. 2011).

\section{The demise of social partnership in Ireland}

After nearly a decade of booming tigerhood, crisis hit Ireland in 2008. The result was that the Irish stock exchange fell by 68 percent and that unemployment increased by 85 percent in one year. Understanding the current situation in the hotel sector in Ireland and the effectiveness of trade union strategies thus necessitates a few words on the effects of the crisis, but also the preceding booming years. According to O'Toole (2009, p. 216), the Irish government "created a bewildering array of property-based tax breaks" with particular incentives for developers, resulting in a 150 percent increase in hotel rooms during a time when visiting tourists increased by 70 percent. A large proportion of developers and investors thus became hoteliers with no other interest in running a hotel than the tax subsidy, a matter that came to complicate industrial relations.

In the end, the Irish government ended up subsidizing the building of hotels with $€ 330$ million, and in effect making the hotel sector unviable (O’Toole 2009). When the National Assets Management Agency (NAMA) took control over some hotels in order to reduce their debts, the hotel trade was rendered even more difficult. The state established NAMA to "take over $€ 90$ billion in loans to developers from banks that would otherwise be insolvent" and this meant that "NAMA would hold more assets than any publicly quoted company in the world." According to one Irish trade union representative, about 50 percent of the hotels went into NAMA receivership. Other hotels had to compete with NAMA hotels, where the latter only need to cover operation costs and not pay mortgage for buildings which have led them to undercut prices.

The union has taken advantage of the fierce competition and embarked upon innovative strategies to which we will return below. The main response to the situation of overcapacity and fierce competition has been to reduce rates, which has also meant a pressure on wages (pers. comm. SIPTU official 2011). During the massive expansion in hotels between 1998 and 2008 the trade union SIPTU was not able to keep pace, and union density dropped. Density building and unionization were further damaged by a combination of business strategies related to tax relief and a critical error on the part 
of the union. Quite a few hotels closed down in order to undertake refurbishment with tax incentives, and the union was involved in negotiating redundancies for its members. However, it did not negotiate that the hotel would reopen as a unionized hotel, which led our informants to wonder whether some hoteliers used this as a combined strategy of tax relief and union-negotiated deunionization.

When it comes to outsourcing and the use of temporary work agencies, union representatives stated that "pay is so bad in hotels they don't need agencies." In other words, merely introducing another employer is not worthwhile as it introduces new costs and lowers the quality of the service (pers. comm. SIPTU official 2011). An inspection made by the National Employment Rights Authority revealed that 78 percent of hotels breached the rate of statutory entitlements and 37 percent did not pay the statutory minimum rate of pay (Buckley 2009). This leads us to a consideration of industrial relations in Ireland.

In Ireland, industrial relations are based on a voluntarist system inherited from the time Ireland was a British colony. Although there was a period with attempts at developing a corporatist model with social partnership agreements negotiated at the national scale, there is no union recognition legislation (Bergene 2010). The process of developing corporatism has, however, seen less influence on the part of the trade union movement and largely been government-initiated. For an analysis of the development of social partnership in Ireland see Allen (2000). As early as in 1962 the government made efforts to establish a body to ensure the coordination of unions and employers. However, the motive was neither to domesticate strong, revolutionary unions nor to ensure a labor-friendly strategy of economic development, but rather to preserve and strengthen Ireland's competitiveness (Suárez 2001). The First National Wage Agreement was reached in 1970, and saw the introduction of considerable government involvement in pay determination in exchange for union involvement in policy discussions. This cooperation was intensified during the recession in the 1980s when high unemployment, reduced union membership, and crisis in public finances compelled a weakened trade union movement to engage in social partnership with the government (Bergene 2010). A Program for National Recovery was entered in 1987, despite some discontent among union members to the wage moderation involved. New social partnership agreements were entered into in 1990, 1994, 1997, 2000, and 2003 and have, according to Suárez (2001), secured moderate wage increases and industrial peace. When the current financial crisis hit Ireland social partnership collapsed, as both government and employers pulled out. According to our informants, this made little difference to low-wage workers, who did not benefit much from the social partnership model in any case.

In contrast to Norway, sector-wide bargaining at the national level is rare. Instead there is a national minimum wage set by Parliament combined with, up until 2011, a legally binding minimum wage for low-income sectors, such as hotels. These rates were negotiated in Joint Labour Committees (JLCs) and were set down in Employment Regulation Orders (EROs). As the financial crisis hit Ireland, employers, spearheaded by the Irish Hotel Federation and followed by the Restaurant Association of Ireland, questioned JLCs and EROs in court on the grounds that they were unconstitutional and won the case. All EROs ceased to have statutory effect from July 2011. JLCs are continued, but the system is reformed so that companies may seek exemption from paying the agreed-upon rate due to financial difficulties and the JLCs are forced to take factors such as competitiveness and (un)employment rates into account. 


\section{Closed shop unionism in Toronto's hotel industry}

Toronto thrives as one of the world's most important hubs for financial services, as well as hosting a substantial sports and entertainment scene, major research and education institutions, and important industries in fields such as television, film, and medical research. Forbes magazine had Toronto ranking $10^{\text {th }}$ on a list of the world's most economically powerful cities in 2008 (Forbes 2008), while the Economist noted how Canada in general seemed more resilient against the recent recession than the United States or Ireland (The Economist 2010). HVS (2011) shows that Toronto offered approximately 37,000 hotel rooms in 2010. Moreover, Toronto has a higher occupancy rate, average room rate, RevPar (profitability per room), and room demand growth than all other Canadian cities. Toronto will most likely continue to experience growing hotel market, even though events such as the financial crisis of 2008/2009 or the SARS epidemic of 2003 (Tufts 2009) brings periodic vulnerability.

According to Panitz and Swartz (2003) and Heron (1996), industrial relations in Canada in general and the Ontario province in particular have become more confrontational in the past three decades following a number of regulatory changes. However, unions in Canada have not experienced a dramatic membership decline (Kumar and Schenk 2006). The percentage of unionized workers in Canada reduced from $34.2 \%$ in 1987 to $30 \%$ in 2003 (compared to a drop from $20.1 \%$ in 1983 to $12.5 \%$ in 2004 in the United States) (Tufts 2007). In Toronto, 34.2\% of workers in accommodation services were unionized in 2010, significantly higher than in other Canadian cities. Hotel wages in Toronto are also higher than in the industry average in Canada (City of Toronto 2011), but they seem to be declining in a relative sense, both when compared to the industry-specific numbers and the national Canadian average.

Breaking from its past of corruption in the 1980s (Getman 2010; Tufts 2006a), the union UNITE HERE Local 75 dominates the accommodation and food service industry in Greater Toronto, claiming a total of 7058 members in October 2011 (pers. comm. UNITE HERE staff 2011). In data drawn from collective agreements and sample of downtown hotels in 2003, Tufts (2007) shows that Local 75 covers about 65 percent of workers, thus being the largest among several competing unions. Local 75 also organizes food service workers.

In addition to being a local union, it is important to grasp how the practices of this local carry the framework of the North-American UNITE HERE organization in general. Getman (2010, p. 35) argues that UNITE HERE is "[...] dedicated to organizing and motivated by a powerful sense of movement." A crucial part of the union's (HERE before 2007) history is the activities, recruitment, and organizing model that were developed at Yale University from the 1980s. Yale students and local workers have been recruited as organizers since the 1980s, and many of these today hold important positions in UNITE HERE across North America, including several of Local 75's current staff. While not all staff and organizers in UNITE HERE come out of the same institution, the "Yale organizing model" is carried across space in this way.

An important characteristic of industrial relations in Toronto hotels is the so-called 'closed-shop' model. While in open shops individual workers can choose whether or not to be unionized, closed shop practices imply that workers have to subscribe to a union if an agreement has been made. This has been based on a system of card-based certification (Riddell 2001). The union attempts to make workers sign a card that authorizes 
the union to represent their interests in collective bargaining. When a specified number of workers have signed, the union is allowed to bargain, and in effect, hotel employees must subscribe to the union. An extra twist to closed shop unionism is that of successorship. If a unionized hotel changes owners, the union authorization follows the building rather than the employer, similar to arrangements in the car manufacturing industry (Holmes 2004).

Card check arrangements are in most instances dependent on so-called neutrality. This is based on voluntary agreements between hotels and unions to allow union organizing. When agreed upon, these agreements "[...]obligate an employer not only to accept a union's campaign to show workers the value of unionization but also to refrain from offering anti-union arguments" (Holmes 2004, p. 18). There have been a number of attempts to restrain the card check and neutrality arrangements in Canada. In 1995, the newly elected progressive conservative Ontario government introduced the Labour Relations and Employment Statute Law Amendment Act (Panitz and Swartz 2003; Sack et al. 1995), limiting the space for calling strike votes and making it harder for unions to achieve negotiating rights at new workplaces. Votes now had to be arranged at each workplace after a quarantine period following the certification of union cards (during which neutrality agreements are not necessarily applied). The bill also made it easier to arrange decertification votes. The closed shop model is thus mediated by both defunct law and the voluntary system upon which most collective agreements and neutrality deals are made.

\section{Strategic choices and contextual differences}

The above descriptions of these three hotel markets portray industrial relations under different types of stress. The hotel sector is experiencing growth during times of uncertainty and this creates competitive pressures triggering restructuring and new labor practices. The hotel industry in all three cities has experienced similar pressures but to different degrees, and their strategic opportunities and limitations are also different. With Toronto's hotel market expanding and undergoing changes, the pressure brought upon by regulatory changes in the 1990s is now felt more strongly. In Oslo, rapid growth in new hotel establishment has triggered rationalization of labor costs through flexibility mechanisms. Dublin has experienced the most fundamental crisis, with a complete restructuring of the industry, the competitive dynamics, and the way labor legislation is being practiced. In addition, these three cities attract large numbers of migrants looking for work. The hotel sector offers a typical low-threshold entry to the labor market. Migrant workers doing hotel work represent a bottom tier in the labor market, and are often part of workplaces where they are poorly integrated and consequently suffer from insufficient representation.

It is within this contextual framework that the unions active in these three urban hotel markets develop and perform their organizing strategies. A look at Table 1 gives us an overview of how the hotel labor markets of Oslo, Dublin, and Toronto compare.

While Toronto is considerably larger than the others, the three cities otherwise represent fairly similar hotel markets. RevPAR in all three cities have been stable or growing in recent years and competes with other national hotel markets, such as Vancouver and Bergen. Occupancy rates, however, are typically lower than top tourist destinations such as Paris or New York and create a competitive environment. 
Table I Three urban labor markets in the hotel sector

\begin{tabular}{|c|c|c|c|c|}
\hline & Population & No of hotels, rooms & Occupancy rate & revPAR \\
\hline Oslo & $\begin{array}{l}\text { I.I million in } \\
\text { metro area }\end{array}$ & $\begin{array}{l}\text { I I } 0 \text { workplaces, I5,000 } \\
\text { rooms }\end{array}$ & 73. 1 percent in 2008 & NOK623 (€ 76)' (2013) \\
\hline Dublin & $\begin{array}{l}1.8 \text { million in } \\
\text { metro area }\end{array}$ & $\begin{array}{l}\text { I } 60 \text { workplaces, 19,000 } \\
\text { rooms }\end{array}$ & 66.9 percent in 2010 & $€ 53$ (20।0) for Dublin \\
\hline Toronto & $\begin{array}{l}<6 \text { million in } \\
\text { metro area }\end{array}$ & $\begin{array}{l}302 \text { workplaces } 2,37,000 \\
\text { rooms }\end{array}$ & 73.5 percent in 2011 & $\begin{array}{l}\$ 101(€ 69)(2010) \text { for } \\
\text { Toronto }\end{array}$ \\
\hline
\end{tabular}

Sources: Central Statistics Office Ireland, City of Toronto 20 I I, Horwath 2009, HVS 20I I, FF archival data base, PWC 20I4, www.EstateNyheter.no, www.hotels.com.

Table 2 Unionization in hotel workplaces

\begin{tabular}{|c|c|c|c|c|}
\hline & $\begin{array}{l}\text { Unionization } \\
\text { rate }\end{array}$ & Union members & Tariff coverage & $\begin{array}{l}\text { Organizing } \\
\text { priorities }\end{array}$ \\
\hline Oslo & $\begin{array}{l}22 \text { percent in the } \\
\text { hotel segment } \\
(2010) \text { (our survey) }\end{array}$ & $\begin{array}{l}2750 \text { in Fellesfor- } \\
\text { bundet Local } 246 \text {, } \\
600 \text { in Local } 249\end{array}$ & $\begin{array}{l}67 \text { of } 110 \text { hotel work- } \\
\text { places under tariff } \\
\text { agreement in } 2012\end{array}$ & $\begin{array}{l}5 \text { staff, no earmarked } \\
\text { organizer positions in } \\
\text { FF Local } 246\end{array}$ \\
\hline Dublin & $\begin{array}{l}\text { Cross-sectoral } \\
\text { national unionization } \\
\text { rate of } 31.5 \% \text { in } 2007\end{array}$ & N/A & $\begin{array}{l}\text { N/A ( } 46 \text { hotels across } \\
\text { Ireland have been } \\
\text { classified as "Fair } \\
\text { Hotels" by SIPTU) }\end{array}$ & $\begin{array}{l}\text { Shift to "organizing } \\
\text { model" means that } \\
\text { most union positions } \\
\text { have organizer duties }\end{array}$ \\
\hline Toronto & $\begin{array}{l}34.2 \text { percent in } \\
\text { accomm. services } \\
\text { for Toronto in } 2010\end{array}$ & $\begin{array}{l}7058 \text { in UNITE } \\
\text { HERE Local } 75 \text { 20 I I, } \\
\text { plus several other } \\
\text { unions }\end{array}$ & 35 percent in 2012 & $\begin{array}{l}20 \text { organizers out } \\
\text { of } 29 \text { staff (including } \\
\text { volunteers) in UNITE } \\
\text { HERE }\end{array}$ \\
\hline
\end{tabular}

Sources: Fellesforbundet.no, Zuberi 2007, City of Toronto 20I I, FF archival data base, pers. comm. UNITE HERE Staff 20I I.

Hotel unionism represents a challenging organizational task under circumstances less than ideal. If we look at the unionization indicators in Table 2, however, some striking dissimilarities appear.

Despite a relatively low unionization rate in Oslo, the tariff coverage is high. Combined with a high organization rate on the capital side (85 percent in 2009), the Norwegian unionization context could be described as highly institutionalized, but with a relatively low level of worker mobilization. The lower figure in Toronto must be understood within the "closed shop" context. Even more important is the strong emphasis on the organizer role in the SIPTU and UNITE HERE organization, a role which is downplayed in the case of Oslo. On the capital side, most of Toronto's hotels are members of the Greater Toronto Hotel Association, which serves as an organization that promotes the interests of the hotel industry and is a major stakeholder in the Ontario tourism industry (GTHA 2014). In Toronto, industrial relations are largely institutionalized at the hotel level/chain level, as 
collective agreements are made with each individual hotel and more general agreements often made at the hotel chain level. As such, there is less contact with the hotel association. In Ireland, about 1000 hotels and guesthouses are affiliated with the Irish Hotels Federation (IHF 2014). The majority of IHF members are nonunion and as in Toronto the IHF does not engage directly in collective bargaining with trade unions. However, it does provide industrial relations assistance and advice to affiliates.

In the labor geography literature, different dimensions of union renewal have been discussed, as they relate to recruitment strategies, the scales of organizing, alliancebuilding in civil society and new targets for action (Jordhus-Lier 2012; Tufts 2007; Wills 2005). In the remainder of this article we analyze our findings, based on a qualitative interview study with union representatives in all three cities, in light of some of the dimensions suggested by this literature. We will focus on union effort to defend the workplace as an organizational entity with a union presence, on attempts to include minority workers in union activities, alliance-building with relevant partners in civil society, and the targeting of customers through ethical consumption campaign.

\section{Consolidating the workplace as union terrain}

What is clear, particularly in the Toronto and Oslo cases, is that a large share of the unions' efforts is steered toward keeping the workplace united as a social community and a place where the union has a legitimate role as a worker representative. UNITE HERE Local 75 distinguishes between internal and external organizing in their model of union recruitment. Internal organizing refers to organizing members of closed shops, while external organizing refers to organizing workers to achieve representation of new workplaces. More broadly, internal organizing can be seen as an activity of making union members aware of their rights and by that becoming able to engage in work matters. The aim of the internal organizing strategy of UNITE HERE Local 75 is to empower the workers in the sense that they know what to look for in employer practices and strategies (pers. comm. Local 75 staff, October 20,2011).

Getman (2010) refers to internal organizing as a way of building a social movement within the workplace, and the solidarity and legitimacy it fosters is crucial in events such as strikes or picketing. Internal organizing follows a routine of "mapping" workplaces and finding "natural leaders" around which groups of workers can organize (pers. comm. UNITE HERE Local 75 representative, 2011). These teams of leaders and their followers represent an ideal unit of internal organizing and are referred to as "committees." The idea is that the committees ensure that union members get sufficient knowledge about their rights in order to conduct day-to-day union work, which again empowers both the members and the union.

In the open shop system of Norway and Ireland, maintaining unity in the workplace is met with other challenges. In Oslo, Fellesforbundet Local 246 is in a constant battle to remain present and strong in every workplace. This task has been complicated by $e x-$ ternalization, as employers are taking advantage of legislative deregulation to outsource room cleaning and other tasks. This represents another threat to the organizational unity of the workplace, as it creates deeper divisions between different categories of workers by placing them under different employers. In terms of unionization, this may also imply that the outsourced workers no longer can be represented by Local 246 . The 
ongoing outsourcing of housekeeping in Oslo hotels meant that even though the hotel union has spent resources and energy on assisting workers who have been outsourced, they are not guaranteed that these members can continue to be members of their union, due to unsolved institutional coverage vis-a-vis rival unions. In the airport area, where several large hotels have been opened relatively recently, the union has however been quite effective in recruiting, establishing new tariff agreements, and assisting workers experiencing outsourcing.

In Toronto, there is no general legislation at the federal or provincial scale to prevent the outsourcing of hotel services. Rather, the collective agreements regulate the use of subcontractors. This means that in some hotels, subcontracting is banned altogether, while in others some departments may allow subcontracting. For example, in one unionized hotel night cleaning in common areas and security services was outsourced. Interestingly, our informants would initially question whether this was outsourcing as such services were not considered hotel work, not even by union representatives. When asked about subcontracting, union representatives maintained that if concessions were given, that would erode the powers of bargaining and possibly dismantle the closed-shop model. Thus, a key strategy for avoiding subcontracting of hotel work is to unionize the hotels to achieve collective agreements to regulate these conditions themselves, rather than waiting for legislation in a relatively hostile political environment.

\section{Regaining union strength}

If we move focus from the workplace toward the overall strategies unions employ across the city (and nationally), a reorientation toward what has been described as the "organizing model" of unionism (see Brecher and Costello 1990; Bronfenbrenner et al. 1998) is detectable both in Toronto and in Dublin. The internal organizing model in Toronto was described in the previous section and represents core values of the "organizing model" such as the ideal of building a strong sense of movement and labor awareness, including the willingness for engaging in various forms of union action. The external organizing of UNITE HERE Local 75 in Toronto is about new recruitment. In Ontario, Canada, this strategy is closely related to the closed shop system and refers to attempts to organize nonunionized workplaces through recruiting new workers, as a way of demonstrating their support for the union as a bargaining representative. This is a very careful process as external organizers must ensure not only a majority of card signings at each hotel, but also ensure a majority vote following the bill that was introduced in 1995 . This is tricky as there has to be five business days between the filing of a vote and the actual vote. During this time, the employer side is free to oppose the unionization by various means, something that may intimidate the workers to vote against unionization. Thus, the closed shop model of external organizing requires substantial organization resources. The balance between successful organizing and protecting the workers from facing serious consequences is challenging: "[...] 95 per cent of non-union workers are afraid to talk to you. You have to take it easy." (pers. comm. UNITE HERE organizer 2011).

The union employs a range of innovative strategies of recruitment in nonunion workplaces (Getman 2010). Local 75 organizers explain that they have to make a selection of which workplaces to target. The smaller apartment-type hotels that have popped up in recent years are difficult as they are scattered around town in small units, whereas 
chain hotels represent more potential. In general Local 75 target chain hotels with low density and those that display harsh attitudes toward unions, but new hotel developments have also been important goals for careful campaigns to make sure developments comply with the principle of neutrality.

For the traditionally white, waiter-dominated hotel union in Oslo a main challenge has been to become more representative among the biggest group of hotel workers, lowpaid hotel cleaners from non-EU countries. The challenges of representation might be quite different in the other cities, according to their organizational histories. The hotel union in Oslo went through a reorientation in the 1990s where recruitment was put higher on the agenda, and where membership fees were lowered to attract new, lowwage workers (Berntsen 2010); 55 percent of the hotel workforce is now from countries other than Norway. While the union leadership still is predominantly Norwegian, union leaders estimate that workers with a minority background account for approximately 80 percent of union representatives at the hotel department level. The unionization rate among non-EU/EEC countries is now as high as 42 percent, compared to 18 percent for Norwegian workers, and as low as 3 percent from other Nordic countries (Jordhus-Lier et al. 2011). While three of five paid staff members are ethnic Norwegians, the leader of the local union branch estimates that 80 percent of shop stewards are not ethnic Norwegians, reflecting the multiethnic workforce in the Oslo area. The orientation toward an "organizing model" that Irish SIPTU has pursued includes concerted efforts to recruit non-Irish workers and to give them positions in the trade union. Primarily this concerns organizer positions, as union representatives acknowledge that shared cultural background is an asset when organizers are to recruit new groups of hotel workers.

Minority shop stewards and organizers are important. But as the case of Fellesforbundet Local 246 testifies, it remains a challenge to recruit workers with a minority background into leadership positions. Further up the ladder, the Norwegian model of industrial relations shows little trace of its multiethnic member base:

\begin{abstract}
"[t]hey are not let in further up the hierarchy. To do so, you simply have to 'move some chairs.' And we have said that it would make sense for us to have a leader who is not an ethnic Norwegian. But we do not think a lot about it. We just want to meet people with a commitment. And we happen to have mostly non-ethnic Norwegians in our local, so that's the people we tend to meet." (pers. comm. Fellesforbundet representative, 2011)
\end{abstract}

A more proactive stance in industrial relations has also been noticeable in the last two decades, and the union depleted its strike fund as a result of downing tools on several occasions in the late 1990s and the early 2000s. After merging with Fellesforbundet, the union has access to a sizable strike fund of NOK1.7 billion (Adresseavisen 2010), but willingness of Fellesforbundet to back hotel workers financially through a long-lasting strike has not yet been tested. Overall, it cannot be argued that Fellesforbundet has made deep-seated reforms toward an "organizing model" of trade unionism.

UNITE HERE Local 75 has showed an even greater commitment to including immigrant workers in organizing, for instance by being involved in local communities and promoting multicultural diversity (Tufts 2006b). The accommodation service industry in Toronto has a large proportion of immigrant workers or "visible" minorities, although there are great variations among the occupational categories. In the two largest categories, 82 percent of "light duty cleaners" (room attendants) were visible minority 
while 44 percent of food and beverage workers shared these characteristics. Citing these numbers from 1996, Tufts (2007, p. 2389) argues that the high union density in accommodation services suggest that "[...] immigrant workers are capable of organising."

\section{Ethical consumerism as union tactic}

One of the more innovative ways to promote neutrality is through ethical consumerism. This typically involves campaigns that either target hotels or chains that oppose neutrality or demonstrate malpractice, or those that promote hotels or hotel chains with sound labor practices. In general, there is a strong support for trade unionism in Norway. Moreover, repeated exposure of malpractice by employers and contractors in the hotel industry has arguably created a strong support for the demands of hotel workers in public opinion (e.g., Elstad 2007; Fremmelid 2011). But while trade unionists have been visible in public debate and in media when these cases have received attention, there has been no concerted effort to facilitate for ethical consumption in the hotel industry except a page on Fellesforbundet's web site where hotels with collective agreements are listed.

The Irish case clearly tells of unionism under much less stable conditions that the Canadian and Norwegian cases. Here, union renewal has a different sense of necessitydeunionization being the other option. As part of a process of union renewal, SIPTU launched the Fair Hotels campaign in May 2010. The strategy is based on thorough research which was initiated in March 2009, starting with compiling a directory of union hotels with a short description of each, thus mapping the major hotel chains in Ireland and the presence of SIPTU in them. The Fair Hotels campaign is, in other words, based on a detailed research report from 2007 on the dynamics of the hotel industry, the composition of the workforce, identifying market segments, and providing overview fiscal incentives. The conclusion was that the business tourism segment should be targeted, since the labor movement would have more leverage. When zooming in on targets, it was acknowledged that quantitative data should inform decisions.

The internal researcher conducting this work made a presentation at a national hotels meeting, and proposed a campaign aimed at raising public awareness of exploitation in the hotel sector and at encouraging people to use unionized hotels. Drawing on insights from the (de)merits of ethical trading initiatives, the campaign was launched employing their discourses and wrapping, but with a different content. The internal researcher argued that the discourse of ethical consumerism would be more effective than the traditional union discourse of boycott and blacklist. It is an ethical consumer campaign, in so far as consumers are encouraged to support hotels they know treat their workers fairly.

The aim of the campaign is to ensure employer neutrality, unionization, and ultimately collective agreements. This means that hotel managers have to agree to sign an access and neutrality agreement with SIPTU, meaning that they recognize the right of employees to join a union and SIPTU as a union representing workers in the hotel industry. The agreement also states that "[e]mployees can join SITPU without fear of hindrance or discrimination from management, or not join if they so choose." A hard copy brochure and an electronic leaflet were made containing a list of union hotels and were circulated within the union movement and the wider civil society. Additionally, SIPTU launched a website through which reservations could be made. 
Ethical consumerism is an integral part of UNITE HERE Local 75's operations, at both the North American and local scale. For instance, UNITE HERE maintains an internet page with a list of hotels that the public should use in terms of supporting unionized workers (UNITE HERE 2012b). UNITE HERE recently set up a webpage called "Accor Novotel Watch" to raise even more awareness about this concrete campaign against the Accor group (UNITE HERE 2012a), including personal experiences from workers. The union also engages social media, including Facebook and YouTube, to disseminate their activities to the public, as well as getting conventional media attention that engages the public (i.e., Monsebraaten 2012 in a broadly commented article in the Toronto Star). Moreover, designated staff and volunteers work on getting information on who actually stays at the hotels and inform customers about bad practices where they happen. If the main customers of hotels get information from the union that makes them change their business, this can be devastating for the hotels. This background research work includes "[f]inding out market profiles of companies, revenues, alliances, ownership, statistics [...] for instance, if a boycott is pending, there is a lot of research that has to go into it” (pers. comm. UNITE HERE staff 2011).

Moreover, research work that relates to ethical consumerism has to be careful in terms of checking with the union's legal departments to avoid lawsuits that may devastate the organization.

\section{Building strength through alliances}

Using alliance-building as a union strategy in the hospitality sector to compensate for low unionization rates, high turnover, and externalization of employer responsibilities has been suggested by Evans et al. (2007), based on the experiences of the London hotel market, where the unionization rate is as low as 5 percent and extensive subcontracting deteriorate conditions for working and organizing. The Living Wage Campaign initiated by London Citizens represents one of the more encouraging examples of communityoriented unionism, and one which the authors argue could be particularly well-suited for targeting the hotel sector (Evans et al. 2007). In contrast, the Fellesforbundet 246 in Oslo has not received any significant backing from domestic civil society groups, and has not been very active in building support beyond the labor movement. Hence, alliance-building with NGOs and unions elsewhere has been sparse. While Fellesforbundet is a member of the global union federation IUF, union leaders participating in IUF are more focused on supporting the campaigns in other countries than linking up hotel struggles in Norway with local struggles elsewhere.

UNITE HERE Local 75, on the other hand, has made important allies at the local, national, and international scale. In Toronto, Local 75 plays an important part of the Toronto Labour Council's work as a union that reflects the need to profile service workers (pers. comm., Toronto Labour Council leader October 20, 2011). Another important alliance is that of public workers. Local 75 has stood up for OPSEU as well as the Canadian Union of Public Employees (CUPE) in recent rounds of public job cuts by the local governments, whereas OPSEU and CUPE have supported Local 75 in disputes over collective agreements with hotels. Additionally, UNITE HERE Local 75 has received substantial support from unions such as United Steelworkers, the Canadian Auto Workers Union, and the Canadian Union of Postal Workers in the food 
service bargaining campaign in 2012 (pers. comm. UNITE HERE Local 75 staff member 2013). Moreover, the campaign against Novotel hotels has received substantial support from other unions and activists in Toronto and beyond, including the support of the International Union of Food workers (IUF). Both the previous successful Hotel Workers rising campaign in 2004-2006 (Zuberi 2007) and the current campaign for union rights in Accor-owned Novotel hotels across North America illustrate that local union engagement goes beyond the interests of Toronto workers, and in the process Ontario workers are simultaneously securing support from unionists elsewhere (Unite Here 2011).

A similar tendency of alliance-building is visible in Dublin. In the months preceding the launch of the Fair Hotels campaign, it was important to win support for the initiative among allies. Over 50 unions have agreed that only fair hotels will enjoy their patronage as well as a number of civil society organizations, such as migrant and immigrant rights groups, faith-based groups, women's organizations, community organizations, and NGOs. Such organizations may carry influence, since the value of their conference business alone is considerable. For instance, SIPTU (2011) estimated that Irish trade unions would stage 78 conferences, involving 9,150 delegates and 51,075 bed nights between 2010 and 2013. In the context of the financial crisis coupled with the abovementioned overcapacity resulting from previous tax regimes, the Fair Hotels strategy to draw on the purchasing power of civil society has become even more effective since the hotel industry has seen fierce competition.

\section{Conclusion}

Returning to our point of departure, we argue that the Nordic model remains an idealtype rather than a reality in the case of the Oslo hotel sector, whereas the Irish and Canadian examples point to how a more union-hostile environment, institutional differences, and alternative union strategy traditions may be conducive to creative and proactive forms of organizing and campaigning. The Irish case illustrates how a union embedded in a social partnership developed into a classic "servicing union" engaging in wage negotiation at the national level with productivity-enhancing clauses in the agreements, while the relationship to the members were largely problem-solving and professional service (Allen 2009). In this period, SIPTU saw a major decline in union density and membership participation. In tandem with the collapse of Social Partnership SIPTU adopted the "organizing model" with an acute emphasis on recruitment, organizing, and mobilizing, an approach Allen (2009) argues is less compatible with corporatist arrangements. The internal dispute in UNITE HERE that ultimately led to the disaffiliation of "Workers United" (the UNITE side) in 2009-2010 similarly illustrates that it is difficult to reconcile these different models as opinions were split on the issue of servicing-orientation and corporatist forms of cooperation: "[...]it was about fundamental differences in what a union is about" (pers. comm. UNITE HERE Local 75 staff). Collaboration has often been heralded as a strong point of the Nordic model, yet both Allen (2009) and union representatives in SIPTU and UNITE HERE argue that the pressure to achieve consensus with the government, hotels, and employers' associations may seal off grassroots pressures, labor standards, and the wider goal of building a labor movement (Allen 2009; cf. Getman 2010). 
In general, the Norwegian union movement may see little value in adopting the organizing model in an effort to encourage membership participation and embark upon more confrontational and proactive strategies such as the ones witnessed in Toronto and Dublin. Again, this must be seen in relation to political scale, as the organizational innovation in the cases of Toronto and Dublin is both a result of local protagonism, organizational ideals at the national and international (UNITE HERE covers USA and Canada) level, and wider efforts at union renewal partly spurred by external developments threatening "business as usual." In Norway, the need for strategic reform is expressed at a local scale but less so at the national level. When crisis hit Ireland, unions found themselves marginalized to the point where searching for alliance-partners and building report with consumers were seen as survival techniques. After all, the regulatory environment offered little help. Similarly, the increasing coercion on unions and the institutional factor of the closed shop model characterizing North American and Toronto unionism are important contextual factors that contribute to strengthening a proactive and often confrontational style of industrial relations. Yet, it is also important to recognize the institutional legacy and the agency of strategy work by the respective unions in focus. For instance, the Fair Hotels campaign was conceived by SIPTU prior to the financial crisis that hit Ireland in 2008, whereas UNITE HERE's internal organizing and mobilizing model can be traced back to the 1970s.

Even though contexts differ in many ways, the contrast between the strategies hotel unions have employed in Norway and the other two cases is startling. The Norwegian model of consensus-based industrial relations is still deemed successful at a national level and Fellesforbundet remains a powerful organization that has managed to remain strong in their traditional core sectors. Yet, the need for a fundamental strategic renewal in the hotel sector and other low-wage sectors is not something that has been clearly expressed from the leadership of Fellesforbundet. The supposedly "union-friendly" environment in Oslo has not led to strong organization or representation of hotel workers as compared to unions in more neoliberal contexts, even though the recruitment of lowwage, minority workers has had some success in recent years. As such, hotel unionism in Oslo bears little resemblance to an ideal-type unionism of the "Nordic model" based on high unionization rates and levels of codetermination. That said, weak Norwegian hotel unions do not necessarily reflect poor working conditions or employment practices. Rather, the Norwegian case indicates that union strength at a national level cannot be used to "read off" the ability of workers to influence decisions in the workplace or the wider labor market. Despite these contextual differences, we argue that important inspiration can be drawn from the Toronto and Dublin cases. For instance, the strategy of promoting labor rights awareness among both existing and potential union members as seen in Toronto is a strong case of building hotel worker empowerment. We also argue that the "Fair Hotels" campaign in Ireland can inspire Norwegian unions as an example of union innovation that exploits associational power as well as the growing trend of ethical consumerism.

\section{References}

Adresseavisen. (2010) 1,7 milliarder i Fellesforbundets streikekasse [1.7 billion in Fellesforbundet's strike fund]. Adresseavisen April 14, 2010. 
Aguiar L and Herod A. (2006) The dirty work of neoliberalism. Oxford: Basil Blackwell.

Allen K. (2000) The Celtic Tiger: The myth of social partnership in Ireland. Manchester: Manchester University Press.

Allen K. (2009) Social partnership and union revitalisation. In: Gall, G. (ed.) The Future of Union Organising. Basingstoke: Palgrave Macmillan. 45-62.

Bergene AC. (2010) Preaching in the desert or looking at the stars? A comparative study of trade union strategies in the auto, textile and garment, and maritime industries University of Oslo, 1-427.

Berntsen H. (2010) Alle rettigheter! Hotell- og restaurantarbeiderne i service og strid giennom 75 ar [Complete rights! Hotel and restaurant workers at service and in battles through 75 years], Oslo: Gyldendal.

Brecher J and Costello T. (1990) Building bridges: The emerging grassroots coalition of labour and community. New York: Monthly Review Press.

Bronfenbrenner K, Friedman S, Hurd RW, et al. (1998) Organizing to win: New research on union strategies. Ithaca: Cornell University Press.

Buckley, E. (2009) Fair Hotels Campaign. Research Strategy and Tactics. SIPTU, Dublin.

City of Toronto. (2011) “2010 industry profiles", City of Toronto. Toronto: http://www. toronto.ca/invest-in-toronto/labour_force_industry_profiles.htm.

Economist. (2010) Canada's resilient economy: The Goldilocks recovery. The Economist, May 6, 2010.

Elstad L. (2007) En såkalt drittjobb [A so-called shitty job], Oslo: Forlaget Manifest.

Evans Y, Wills J, Datta K, et al. (2007) 'Subcontracting by stealth' in London's hotels: Impacts and implications for labour organising. Just Labour: A Canadian Journal of Work and Society 10: 85-97.

Forbes. (2008) World's most economically powerful cities. Forbes magazine online. http:// www.forbes.com/2008/07/15/economic-growth-gdp-biz-cx_jz_0715powercities.html.

Fremmelid T. (2011) Lønna uteblir gang etter gang. Romerikes Blad.

Getman JG. (2010) Restoring the power of unions: It takes a movement. New Haven, CT: Yale University Press.

Gray M. (2004) The social construction of the service sector: Institutional structures and labour market outcomes. Geoforum 35: 23-34.

GTHA. (2014) About Greater Toronto Hotel Association. http://www.gtha.com/AboutGTHA.aspx.

Herod A and Aguiar L. (2006) Introduction: Cleaners and the dirty work of neoliberalism. Antipode, 38: 425-434.

Heron C. (1996) The Candian Labour Movement. Toronto: James Lorimer and Company Ltd.

Holmes J. (2004) Re-scaling collective bargaining: Union responses to restructuring in the North American auto industry. Geoforum 35: 9-21.

Horwath (2009). Norsk Hotellnæring 2009 [The Norwegian Hotel Industry]. 13 ${ }^{\text {th }}$ edition. Horwath Consulting HTL: 1-47.

Hudson R. (2001) Producing places. New York: Guilford Press.

HVS. (2011) Canadian monthly lodging outlook: A look at the Canadian lodging industry in 2011 and ahead to 2012. http://www.hvs.com/Content/3198.pdf.

IHF. (2014) About the Irish Hotels Federation. http://www.ihf.ie/content/about-us.

Jordhus-Lier DC. (2012) The geographies of community-oriented unionism: Scales, targets, sites and domains of union renewal in South Africa and beyond. Transactions of the Institute of British Geographers OnlineFirst April 10, 2012.

Jordhus-Lier DC, Bergene AC, Knutsen HM, et al. (2010) Hotel workplaces in Oslo and Akershus. NIBR Working Paper 2010:106. Oslo: Norwegian Institute for Urban and Regional Research, 1-30. 
Jordhus-Lier DC, Aasland A, Underthun A, Tyldum G (2011) Fragmenterte arbeidsplasser? En spørreundersøkelse blant hotellarbeidere i Oslo og Akershus [Fragmented workplaces? A survey among hotel workers in Oslo and Akershus]. Søkelys på arbeidslivet 2011: $355-373$.

Kumar P and Schenk C. (2006) Union renewal and organizational change: A review of the literature. In: Kumar P and Schenk C (eds) Paths to Union Renewal: Canadian experiences. Peterborough: Broadview Press. 29-60.

McNeill D. (2008) The hotel and the city. Progress in Human Geography 32: 383-398.

Mjøset L. (1987) Nordic economic policies in the 1970s and 1980s. International Organization 41: 403-456.

Moene KO. (2007) Den nordiske modellen [The Nordic Model]. ESOP working paper: $1-12$.

Monsebraaten L. (2012) Hotel workers struggle to unionize for better pay and benefits. The Star, March 5, 2012, http://www.thestar.com/news/article/1140854--hotel-workersstruggle-to-unionize-for-better-pay-and-benefits? $\mathrm{bn}=1$.

Moody K. (1997) Workers in a lean world: Unions in the international economy, New York: Verso.

O’Toole F. (2009) Ship of Fools: How stupidity and corruption sank the Celtic Tiger. London: Faber and Faber.

Panitz L and Swartz D. (2003) From consent to coercion. Aurora, Ontario: Garamond Press.

PWC (2014). "Room to grow: European cities hotel forecast for 2014 and 2015. 18 gateway cities, Amsterdam to Zurich" Report by PriceWaterhouseCoopers March 2014: 1-56.

Riddell C. (2001) Union suppression and certification success. Canadian Journal of Economics 34: 396-410.

Sack J., Mitchell M., Price S. (1995) The 1995 Act- $\$ 1.16$, The Ontario Labour Relations Board Law and Practice. Toronto: Butterworths.

SIPTU (2011) Liberty March, Vol. 10, No. 3. http://www.siptu.ie/bulletin/pdf/1305139833 LibertyMarch.pdf.

Suárez S. (2001) Political and economic motivations for labour control: A comparison of Ireland, Puerto Rico, and Singapore. Studies in Comparative International Development 36: 54-81.

Thelen K. (2001) Varieties of labour politics in the developed democracies. In: Hall PA and Soskice DW (eds) Varieties of Capitalism. Oxford: Oxford University Press. 71-103.

Tufts S. (2006a) Renewal from different directions: The Case of Unite-Here, Local 75. In: Kumar P and Schenk C (eds) Paths to Union Renewal: Canadian Experiences. Peterborough: Broadview Press. 201-219.

Tufts S. (2006b) We make it work: The cultural transformation of hotel workers in the city. Antipode 38: 350-373.

Tufts S. (2007b) Emerging labour strategies in Toronto's hotel sector: Toward a spatial circuit of union renewal. Environment \& Planning A 39: 2383-2404.

Tufts S. (2009) Hospitality unionism and labour market adjustment: Toward Schumpeterian unionism? Geoforum 40: 980-990.

UNITE HERE (2011) International union federation stands up for Accor Novotel workers in Ontario. http://www.uniteherelocal75.org/detail.php?newsid=78.

UNITE HERE. (2012a) Accor Novotel Watch, homepage. http://www.accornovotelwatch.org/.

UNITE HERE. (2012b) Hotel list Toronto. http://www.hotelworkersrising.org/HotelGuide/results.php?loc_city=Toronto\&property_name $=\& l o c \_s t a t e=\& l o c \_c o u n t r y=\&$ msa_id=\&orderby=property_name\&Submit.x=45\&Submit.y=9.Wills J. (2005) The geography of union organising in low-paid service industries in the UK: Lessons from the T\&G's campaign to unionise the Dorchester Hotel. Antipode 37: 139-159. 
Wills J. (2008) Making class politics possible: Organizing contract cleaners in London. International Journal of Urban and Regional Research 32: 305-323.

Wrench J. (2004) Trade union responses to immigrants and ethnic inequality in Denmark and the UK: The context of consensus and conflict. European Journal of Industrial Relations 10: 7-30.

Zampoukos K and Ioannides D. (2011) The tourism labour conundrum: Agenda for new research in the geography of hospitality workers. Hospitality \& Society 1: 25-45.

Zuberi D. (2007) Organizing for better working conditions and wages: The Unite Here! Hotel Workers Rising Campaign. Just Labour: A Canadian Journal of Work and Society 10: 60-73.

\section{End notes}

${ }^{1}$ Currency conversion carried out at www.xe.com on August 14, 2014.

${ }^{2}$ It is difficult to find accurate numbers of hotels as there are definitional discrepancies (i.e., the definition of the metropolitan area and the definition of what is a hotel. For instance, Ireland typically includes small Bed and Breakfast, while Toronto hotels typically run larger than Oslo and Dublin hotels. The number for Toronto was generated by searching for hotels in Toronto, Ontario, Canada at www.hotels.com on three random dates in August 2014. A similar search was conducted for Dublin (295) and Oslo (96). 